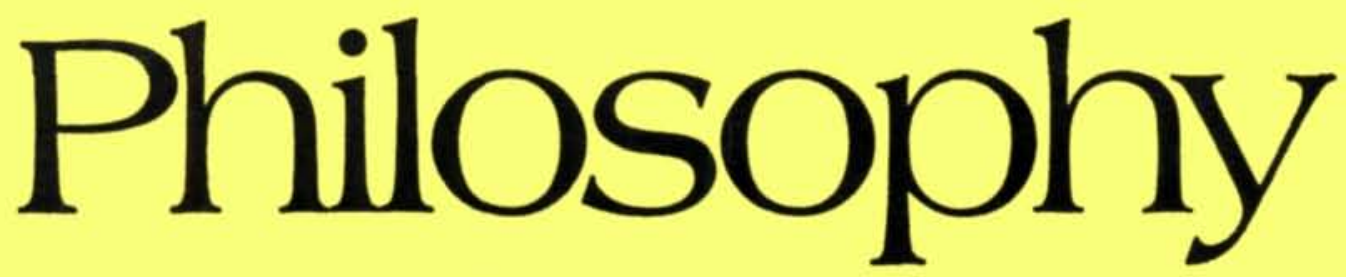

The Journal of the Royal Institute of Philosophy Published by Cambridge University Press

Wittgenstein's Indeterminism

Richard K. Scheer

Do Animals Feel Pain?

\title{
Peter Harrison
}

Philosophizing

A. B. Palma

Freedom and Human Nature

Antony Flew

What is this Thing called 'Love'?

Frances Berenson

Substance and Selfhood

E. J. Lowe

DISCUSSION

NEW BOOKS

BOOKNOTES 


\section{The Royal Institute of Philosophy}

\section{Founded in 1925}

President Lord Quinton, M.A., F.B.A.

Chairman of the Council Professor Stewart R. Sutherland, M.A., Hon. L.H.D.

Vice-Chairman of the Council Professor Godfrey N. A. Vesey, M.A., M.Litt.

Hon. Director Professor A. Phillips Griffiths, B.A., B.Phil.

Hon. Editor of 'Philosophy' Renford Bambrough, M.A.

Secretary Ingrid M. Purkiss, B.A. Treasurer Richard J. Newton, M.A.

\section{Membership}

The Institute welcomes as members any who are interested in philosophy. There are centres of the Institute at the University of Newcastle upon Tyne and the University College of North Wales. In these centres, and at the London headquarters, an annual programme of lectures is arranged. Members receive copies of Philosophy but not the Supplements (see under Subscriptions below) but these are available to members at a $20 \%$ discount.

The annual subscription is $\$ 20.00, \$ 45.00$ in the USA and Canada. For full-time students and those registered as unemployed the subscription is $\$ 10.00$ or $\$ 22.00$. Membership is effective from 1 April of any year. Application should be made to THE SECRETARY, ROYAL INSTITLTE OF PHILOSOPHY, it GORDOX SOCARE, LONDON, WCIH 0.AG. Members are reminded that subscriptions fall due on 1 April (receipts to renewing members will be issued only on request).

\section{Philosophy}

The editorial policy of the journal pursues the aims of the Institute: to promote the study of philosophy in all its branches: logic, metaphysics, epistemology, ethics, aesthetics, social and political philosophy and the philosophies of religion, science, history, language, mind and education. The Institute is not committed to any school or method and its membership is not restricted to those with special qualifications in philosophy. Contributors are expected to avoid all needless technicality.

(C) The Royal Institute of Philosophy 1991

\section{Permission}

For permission to reproduce material from Philosophy, please apply to Cambridge or the American Branch of Cambridge University Press.

ISI Tear Sheet Service, 3501 Market Street, Philadelphia, Pa. 19104, USA, is authorized to supply single copies of separate articles for private use only.

\section{Subscriptions}

Philosophy (ISSN 0031-8191) is published quarterly in January, April, July and October. The well-established RIP Lecture Series, formerly published separately, and collections of the papers delivered at the conferences organised by the Royal Institute of Philosophy are now published as RIP Supplements and included in the subscription price to Philosophy. Three supplementary volumes will be published in 1991. The subscription price of volume 66 (1991) (which includes postage) is $£ 79.00$ in the UK, 682.00 elsewhere (US $\$ 157.00$ in the USA and Canada). Single parts cost $\$ 15.00$ (US $\$ 29.00$ in the USA and Canada) plus postage. Four parts form a volume. Orders, which must be accompanied by payment, may be sent to any bookseller or subscription agent or direct to the publishers: Cambridge University Press, The Edinburgh Building, Shaftesbury Road, Cambridge CB2 2RU; or in the USA and Canada, Cambridge University Press, Journals Department, 40 West 20th Street, New York, NY 10011 4211. Copies of the journal for subscribers in the USA and Canada are sent by air to New York to arrive with minimum delay. Second class postage paid at New York, NY and at additional mailing offices. POSTMASTER: send address changes in USA and Canada to Cambridge University Press, 110 Midland Avenue, Port Chester, New York, NY 10573-9864.

Back volumes are available from Wm. Dawson \& Son Ltd, Cannon House, Folkestone, Kent.

Microfilmed copies of back numbers of Philosophy are available from Microform Limited, East Ardsley, Wakefield, West Yorkshire, WF3 2AT. 